\title{
DESIGN OF LIQUID-STORAGE TANK: RESULTS OF SOFTWARE MODELING VS CALCULATIONS ACCORDING TO EUROCODE
}

\author{
Professional paper / Stručni rad
}

Matko Gulin

(Received: 21 October 2017; accepted: 21 November 2017)

University of Split, Faculty of Civil Engineering, Architecture and Geodesy, mag.ing.aedif.

Ivana Uzelac

University of Split, Faculty of Civil Engineering, Architecture and Geodesy, PhD

Jakub Dolejš

Czech Technical University in Prague, Faculty of Civil Engineering, Assistant Professor

Ivica Boko

University of Split, Faculty of Civil Engineering, Architecture and Geodesy, Full Professor

Corresponding author: ivica.boko@gradst.hr

Abstract: The objective of this article is to show the design process of a liquid-storage tank shell according to Eurocode and compare the results obtained using the norms with those from a finite element method (FEM) analysis. The calculations were performed for an aboveground vertical steel water-storage tank with a variable thickness wall and stiffening ring on top. First, the types of liquid storage tanks are briefly explained. Second, the given tank is described. Third, an analysis of the tank wall according to the Eurocode was carried out. The FEM analysis was performed using the Scia Engineer ver. 17 software. Finally, all the results are presented in tables and compared.

Keywords: shells; modeling; steel-structure; earthquake; buckling

\section{PRORAČUN SPREMNIKA ZA TEKUĆINE: USPOREDBA REZULTATA RAČUNALNOG MODELA I ANALIZE PREMA EURONORMI}

Sažetak: Svrha ovoga članka je prikazati postupak proračuna plašta spremnika za tekućine prema euronormi, te tako dobivene rezultate usporediti s rezultatima računalnog modela. Primjer na kojemu je napravljena usporedba je nadzemni čelični spremnik za vodu sa stijenkom promjenjive debljine i ukrutnim prstenom na vrhu. Najprije su ukratko predstavljeni tipovi spremnika za tekućine, zatim je opisan spremnik na kojemu je izvršena analiza, a potom je proveden proračun stijenke spremnika prema euronormi. Analiza metodom konačnih elemenata odrađena je na numeričkom modelu, koristeći programski paket Scia Engineer 17. Na kraju su tablično prezentirani i uspoređeni rezultati obje analize.

Ključne riječi: ljuska; modeliranje; čelična konstrukcija; potres; izbočivanje 


\section{INTRODUCTION}

Storage tanks are containers that hold liquids, compressed gases, or mediums used for the short or long-term storage of heat or cold [1]. They can be vertical and horizontal, aboveground, semi underground, and underground, carry static and dynamic loads, and work under vacuum or over pressure, upon the wind, seismic, and temperature influences [2]. The largest segment corresponds to the aboveground steel vertical tanks, which are sheet structures with cylindrical form [3]. They are designed as flat bottom cylindrical vessels with different kinds of roofs [4]. Some tanks can have no roof, but have a wind girder ring welded on the outside; other tanks have a stiffening ring to prevent local buckling of the shell under wind pressures; and there are tanks with several uniformly spaced rings. The cylinder itself is formed by welded curved plates. The walls can have constant or variable thickness at different elevations. The type of foundation construction depends on the size and function of the aboveground steel tank (AST), bearing capacity of soil, level of underground water, need of anchorage, and owners' capabilities [5]. The most commonly used types of foundations are those from compacted soil, reinforced concrete ring that is not placed under the shell, reinforced concrete ring wall, and reinforced concrete slab foundation [2]. The steel tank and silo design process should be performed according to the EN 1993-4-1 and EN 1993-4-2 Eurocode norms, emphasizing that newer versions of the norms include some changes in the buckling resistance calculations, which are described in [6].

The Eurocodes used for load analysis are [7-10]. For seismic analysis, [11] and [12] are required. The design standard [13] was also used.

For tank design, the most important parameter is the consequence class (CC) because it indicates the level of structural reliability, which determines the choice of method of structural analysis. This paper analyses the water tank characterized as class CC1 (agricultural tanks and tanks containing water), and thus, the theory of membrane stress with simplified formulas for local buckling is used. In [10], four basic boundary states for steel shells are defined, and methods for determining the stresses and internal forces in the given state are presented. In the following sections, the buckling limit state (LS3) stresses are obtained by linear elastic analysis (LA).

\section{CHARACTERISTICS OF ANALYZED STRUCTURE}

The structure presented in this article is an aboveground water storage tank with capacity of $5000 \mathrm{~m}^{3}$, covered with an aluminum geodesic dome. The building material of the cylinder is steel with the following properties: yield strength $\mathrm{f}_{\mathrm{y}}=235 \mathrm{~N} / \mathrm{mm}^{2}$, tensile strength $\mathrm{f}_{\mathrm{u}}=360 \mathrm{~N} / \mathrm{mm}^{2}$, and volume weight $\gamma_{\mathrm{s}}=78.5 \mathrm{kN} / \mathrm{m}^{3}$. The outer diameter is $20700 \mathrm{~mm}$, with changes in the thickness of the walls inside of the cylinder. The total height of the cylinder walls is $16000 \mathrm{~mm}$, and the operational height of the stored water is $15000 \mathrm{~mm}$, as shown in Figure 1. The tank is designed according to the standards in [13].

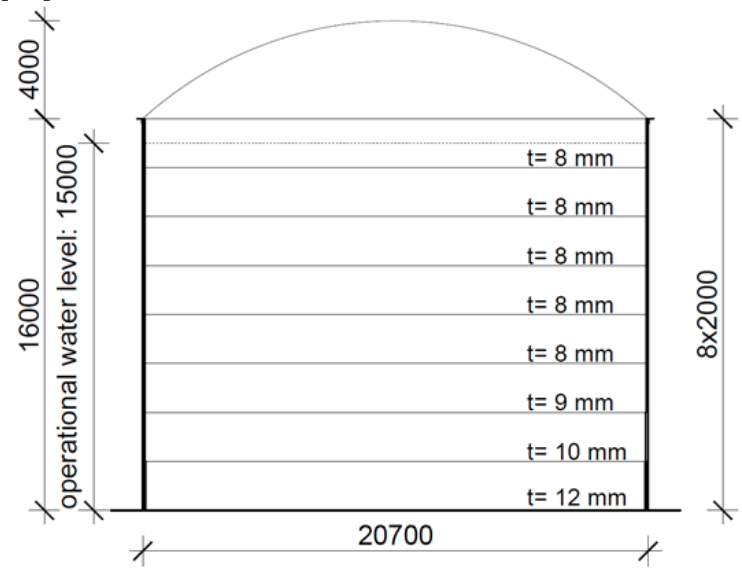

Figure 1 Cross section of the tank with dimensions (in $\mathrm{mm}$ )

According to reference [13] (Chapter 9.2), the required thickness $t$ of the wall is defined as the highest value between (1) and (2), where (1) represents the shell thickness required for the design conditions while (2) represents the shell thickness required for the test conditions. 
$e_{c}=\frac{D}{20 \cdot S} \cdot\left[98 \cdot W \cdot\left(H_{c}-0.3\right)+p\right]+c$

$e_{t}=\frac{D}{20 \cdot S_{t}} \cdot\left[98 \cdot W_{t} \cdot\left(H_{c}-0.3\right)+p_{t}\right]$

The corrosion allowance was taken as $c=1.5 \mathrm{~mm}$. The distances from the bottom of the course, under consideration to the height, $\mathrm{H}_{c}$ defined in 9.2.1 [13] are listed in Table 1. For the design pressure smaller than 10 mbar, the pressure values $p$ and $p_{t}$ are 0 and the maximum design densities of the contained and test medium are $W=W_{t}=1 \mathrm{~kg} / l$. According to [13], the allowable design (3) and test (4) stresses are:

$S=\min \left[\frac{2}{3} \cdot \sigma_{r}=\frac{2}{3} \cdot 235=156.66 ; 260\right]=156.66 \mathrm{~N} / \mathrm{mm}^{2}$

$S_{t}=\min \left[0.75 \cdot \sigma_{r}=0.75 \cdot 235=176.25 ; 260\right]=176.25 \mathrm{~N} / \mathrm{mm}^{2}$,

The values of the required thicknesses for each shell course are listed in Table 1.

Table 1 Required (e) and adopted ( $\mathrm{t}$ ) shell thickness

\begin{tabular}{ccccc} 
course no. & $\mathrm{H}_{\mathrm{c}}[\mathrm{m}]$ & $\mathrm{e}_{\mathrm{c}}[\mathrm{mm}]$ & $\mathrm{e}_{\mathrm{t}}[\mathrm{mm}]$ & $\mathrm{t}[\mathrm{mm}]$ \\
\hline 1 & 15.0 & 11.01 & 8.46 & 12 \\
\hline 2 & 13.0 & 9.72 & 7.30 & 10 \\
\hline 3 & 11.0 & 8.42 & 6.15 & 9 \\
\hline 4 & 9.0 & 7.13 & 5.00 & 8 \\
\hline 5 & 7.0 & 5.84 & 3.86 & 8 \\
\hline 6 & 5.0 & 4.54 & 2.71 & 8 \\
\hline 7 & 3.0 & 3.25 & 1.55 & 8 \\
\hline 8 & 1.0 & 1.95 & 0.40 & 8
\end{tabular}

\section{LOAD VALUES}

The loads were calculated according to [8] and the specific location: Croatia, Split, latitude $43^{\circ} 30^{\prime} \mathrm{N}$ longitude $16^{\circ}$ $27^{\prime} \mathrm{E}$, and altitude $25 \mathrm{~m}$. The analysis procedure is explained in detail in [14], but because of simplicity, the selfweight, liquid induced, and snow loads are not shown in this article. The wind and seismic analysis are described with additional detail.

Self-weight of the cylinder wall and roof weight per meter of cylinder perimeter is $W_{\mathrm{t}}=11.65 \mathrm{kN} / \mathrm{m}^{\prime}$, in which the density of steel $S 235$ is $\gamma_{s}=78.5 \mathrm{kN} / \mathrm{m}^{3}$, and the weight of the aluminum dome is $10.3 \mathrm{~kg} / \mathrm{m}^{2}$. The liquid induced load according to [8] (Chapter 7) is $p(z)=147.2 \mathrm{kN} / \mathrm{m}^{2}$. The snow loads according to [15] (Chapter 5) are: characteristic value $s_{k}=0.5 \mathrm{kN} / \mathrm{m}^{2}$, and coefficients $C_{e}$ and $C_{t}$ are 1.0 , so that the snow load perpendicular to the surface of the roof dome is $s=0.40 \mathrm{kN} / \mathrm{m}^{2}$. The basic wind pressure on the shell $q_{b}$ according to [16] (Chapter 7.9), where $v_{b, 0}=25 \mathrm{~m} / \mathrm{s}$ and $C_{\text {season }}=C_{\text {dir }}=1.0$, is $q_{b}=0.39 \mathrm{kN} / \mathrm{m}^{2}$. Different peak velocity wind-pressure values perpendicular to the cylinder wall are determined depending on the exposure factor, for type I terrain category, according to [14].

Table 2 Wind pressure values perpendicular on the cylinder wall

\begin{tabular}{|c|c|c|c|}
\hline$z[\mathrm{~m}]$ & $\mathrm{Ce}(\mathrm{z})$ & $\mathrm{q}_{b}\left[\mathrm{kN} / \mathrm{m}^{2}\right]$ & $\mathrm{q}_{\mathrm{p}}(\mathrm{Ze})\left[\mathrm{kN} / \mathrm{m}^{2}\right.$ \\
\hline 2 & 2.0 & \multirow{8}{*}{0.39} & 0.78 \\
\hline 4 & 2.2 & & 0.86 \\
\hline 6 & 2.5 & & 0.98 \\
\hline 8 & 2.6 & & 1.01 \\
\hline 10 & 2.8 & & 1.09 \\
\hline 12 & 2.9 & & 1.13 \\
\hline 14 & 3.0 & & 1.17 \\
\hline 16 & 3.1 & & 1.21 \\
\hline
\end{tabular}


According to [10], Annex D 1.3.2., the characteristic wind distribution perpendicular to the cylinder, described in detail in [14], can be simplified using expression (5):

$q_{\text {eq }}=k_{w} \cdot q_{w, \max }$

where $q_{w, \max }$ is the peak velocity (maximal) pressure (marked as $q_{p}\left(z_{e}\right)$ in Table 2 ) and $k_{w}$ is determined by expression (6), and has to be inside the range $0.65<\mathrm{k}_{\mathrm{w}}<1.0$ :

$k_{\mathrm{w}}=0.46\left(1+0.1 \sqrt{\omega / C_{\theta} \cdot r / t}\right)$

where the dimensionless length parameter $\omega=1 / \sqrt{r / t}$, and $C_{\theta}=1.0$ is taken from [10] (Table D.3), according to the boundary conditions. $k_{w}$ is higher than 1.0 in all cylinder courses, so $k_{w}=1.0$ is adopted. The suction pressure on the inner surface of the tank, according to [10] (Annex B Chapter 2.9) for round cylindrical tanks with small openings and with an adequate ventilation system, is determined by the internal pressure coefficient $\mathrm{C}_{\mathrm{p}}$. The recommended value of -0.4 is used, so $q_{s}=-0.48 \mathrm{kN} / \mathrm{m}^{2}$.

According to [12] (Annex A Chapter A.3.2.2), the simplified procedure for fixed base cylindrical tanks has been used. The ground acceleration $\left(a_{g}\right)$ is $0.22 \mathrm{~g}$, and the response spectrum type 1 for foundation soil type A was chosen. The steel tank with radius $(\mathrm{R})$ of $10.35 \mathrm{~m}$ is fully anchored to a concrete mat foundation. The total mass of water in the tank $(\mathrm{m})$ is $5.05 \times 10^{6} \mathrm{~kg}$. The total mass of the tank wall $\left(\mathrm{m}_{\mathrm{w}}\right)$ is $73.7 \times 10^{3} \mathrm{~kg}$, and the height of its center of gravity $\left(h_{w}\right)$ is $7.43 \mathrm{~m}$. The mass of the tank roof $\left(\mathrm{m}_{\mathrm{r}}\right)$ is $3.5 \times 10^{3} \mathrm{~kg}$, and the height of its center of gravity $\left(\mathrm{h}_{\mathrm{r}}\right)$ is $18 \mathrm{~m} .0 .5 \%$ and $2 \%$ damped elastic response spectra are used. First, the equivalent uniform thickness of the tank wall is calculated by the weighted average method, using weights equal to the distance from the liquid surface, $\mathrm{s}=9.59 \mathrm{~mm}$. The modulus of elasticity of steel is $\mathrm{E}=2.1 \times 10^{11} \mathrm{~N} / \mathrm{m}^{2}$, while water density equals $\rho=1000 \mathrm{~kg} / \mathrm{m}^{3}$. For $\mathrm{H} / \mathrm{r}=1.45$ the coefficient values for first impulse and convective mode of vibrations are interpolated from [12] (Table A.2).

Table 3 Coefficients $C_{j}$ and $C_{c}$ for the natural periods, masses $m_{j}$ and $m_{e}$ and heights $h_{i}$ and $h_{e}$ from the base of the point of application of the wall pressure resultant, for the impulsive and convective components

\begin{tabular}{llllllll}
\hline $\mathrm{C}_{\mathrm{i}}$ & $\mathrm{C}_{c}$ & $\mathrm{~m}_{\mathrm{i}} / \mathrm{m}$ & $\mathrm{m}_{\mathrm{c}} / \mathrm{m}$ & $\mathrm{h}_{\mathrm{i}} / \mathrm{H}$ & $\mathrm{h}_{\mathrm{c}} / \mathrm{H}$ & $\mathrm{h}_{i} / \mathrm{H}$ & $\mathrm{h}_{c}{ }^{\prime} / \mathrm{H}$ \\
\hline 6.09 & 1.48 & 0.672 & 0.328 & 0.437 & 0.683 & 0.572 & 0.739 \\
\hline
\end{tabular}

The natural periods of the impulsive and the convective responses are calculated using expressions (7) and (8).

$T_{\text {imp }}=C_{i} \cdot \frac{H \cdot \sqrt{\rho}}{\sqrt{\mathrm{s} / \mathrm{R}} \cdot \sqrt{E}}$

$T_{\text {con }}=C_{c} \cdot \sqrt{R}$

Using coefficients from Table 3 , the impulsive and convective mases are $m_{i}=3.39^{*} 10^{6} \mathrm{~kg}$ and $m_{c}=1.65^{*} 106$ $\mathrm{kg}$, respectively. The impulsive spectral acceleration, for $\mathrm{T}_{\mathrm{imp}}=0.207 \mathrm{~s}$ obtained from the $2 \%$ damped elastic response spectrum, is $S_{e}\left(T_{i m p}\right)=5.40 \mathrm{~m} / \mathrm{s}^{2}$. The convective spectral acceleration for $T_{\text {con }}=4.761 \mathrm{~s}$, obtained from the $2 \%$ damped response spectrum, is $S_{e}\left(T_{c o n}\right)=0.245 \mathrm{~m} / \mathrm{s}^{2}$.

The base shear force, determined according [12], Annex A.3.2.2.2., is

$Q=\left(m_{i}+m_{w}+m_{r}\right) \cdot S_{e}\left(T_{\text {imp }}\right)+m_{c} \cdot S_{e}\left(T_{\text {con }}\right)$

and is equal to $Q=19127.3 \mathrm{kN}$. The overturning moment above the base plate, and the overturning moment below the base plate, obtained from (10) and (11) are as follows

$$
\begin{aligned}
& M=\left(m_{i} \cdot h_{i}+m_{w} \cdot h_{w}+m_{r} \cdot h_{r}\right) \cdot S_{e}\left(T_{\text {imp }}\right)+m_{c} \cdot h_{c} \cdot S_{e}\left(T_{\text {con }}\right) \\
& M^{\prime}=\left(m_{i} \cdot h_{i}{ }^{\prime}+m_{w} \cdot h_{w}+m_{r} \cdot h_{r}\right) \cdot S_{e}\left(T_{\text {imp }}\right)+m_{c} \cdot h_{c}{ }^{\prime} \cdot S_{e}\left(T_{\text {con }}\right)
\end{aligned}
$$

and are equal to $M=127366.0 \mathrm{kNm}$, and $M^{\prime}=164866.8 \mathrm{kNm}$. The maximum vertical displacement of the liquid surface due to sloshing can be obtained by (12), and is equal to $d_{\max }=0.21 \mathrm{~m}$. 
$d_{\max }=0,84 \cdot R \cdot S_{e}\left(T_{\text {con }}\right) / g$

According to [12], Annex A Chapters A.2.2 and A.3.3, the hydrodynamic pressure owing to vertical ground acceleration, does not combine with the shear component or bending moment on the wall or foundation of the tank because of axial symmetry. However, because of the nature of the vertical motion of the tank with acceleration there is an effect of radial breathing. Consequently, owing to vertical ground acceleration in the tank shell, there are stresses from the hydrodynamic pressure, according to Chapter A.2.2, and the pressure caused by deformation of the shell in the radial direction, as defined in A.3.3. As suggested in [12], the total impact on the tank wall $p_{v}$ is equal to the square root of the sum of squares of these two pressures, and the values are listed in Table 4. Hydrodynamic pressure is defined in expression (13), where water density is $\rho=1000 \mathrm{~kg} / \mathrm{m}^{3}$, water level $\mathrm{H}=15 \mathrm{~m}$, coefficient $\varsigma=z / H$ is defined in A.2.1.1, and $A_{v}(t)$ is the type 1 vertical elastic response spectrum acceleration according to [11].

$p_{v r}(\varsigma, t)=\rho \cdot H \cdot(1-\varsigma) \cdot A_{v}(t)$

The radial deformation pressure is calculated using expression (14), where $f(Y)$ depends on the radius to water height ratio. $A_{v}(t)$, which is the acceleration response of a simple oscillator having a frequency equal to the fundamental frequency of the axisymmetric vibration of the tank with the fluid, equals $4.22 \mathrm{~m} / \mathrm{s}^{2}$ with $2 \%$ dampening. The fundamental frequency is $4.81 \mathrm{~s}^{-1}$ from expression [12], A.42.

$p_{v f}(\varsigma, t)=0.815 \cdot f(\gamma) \cdot \rho \cdot H \cdot \cos \left(\frac{\pi}{2} \varsigma\right) \cdot A_{v f}(t)$

(14)

Table 4 Combined hydrodynamic pressure values

\begin{tabular}{ccccc} 
course no. & $z[\mathrm{~m}]$ & $p_{v v}(S, t)\left[\mathrm{N} / \mathrm{mm}^{2}\right]$ & $p_{v r}(S, t)\left[\mathrm{N} / \mathrm{mm}^{2}\right]$ & $p_{v}\left[\mathrm{~N} / \mathrm{mm}^{2}\right]$ \\
\hline 1 & 0.1 & 0.060 & 0.061 & 0.086 \\
\hline 2 & 2 & 0.059 & 0.054 & 0.080 \\
\hline 3 & 4 & 0.055 & 0.045 & 0.071 \\
\hline 4 & 6 & 0.049 & 0.037 & 0.061 \\
\hline 5 & 8 & 0.041 & 0.029 & 0.050 \\
\hline 6 & 10 & 0.030 & 0.020 & 0.036 \\
\hline 7 & 12 & 0.019 & 0.012 & 0.022 \\
\hline 8 & 14 & 0.007 & 0.004 & 0.008
\end{tabular}

\section{LOAD COMBINATIONS}

The general assumptions given in [7] are applicable, but tanks differ from other structures because they are exposed to full loads during most of their life span. Therefore, it is recommended to use [8], Annex A, that defines the partial safety factors, combinations for ultimate limit states (ULS), and serviceability limit states (SLS). According to Table A.2 and expressions (6.10a) and (6.12b), the following load combinations were analyzed for ULS (buckling limit state LS3):

Table 5 Load combinations

\begin{tabular}{|c|c|c|}
\hline Name & Description & \\
\hline $\mathrm{D}$ & Liquid discharge & $" \gamma_{G, j}\left(W_{t}\right) "+" \gamma_{Q, 1} 1.0 T^{\prime}++" \gamma_{Q, i} 0.6(S+W) "$ \\
\hline $\mathrm{I}$ & Imposed loads & $" \gamma_{G, j}\left(\mathrm{~W}_{\mathrm{t}}\right) "+" \gamma_{Q, 1} 1.0 \mathrm{~T} "+\mathrm{p} \gamma_{Q, i} 0.6(S+W)^{n}$ \\
\hline S & Snow & $" \gamma_{G, j}\left(\mathrm{~W}_{\mathrm{t}}\right)^{\prime \prime}+" \gamma_{Q, 1} 1.0 \mathrm{~T}+\mathrm{T}+0.6 \mathrm{~S}^{\prime \prime}$ \\
\hline WF & Wind and full tank & $" \gamma_{G, j}\left(\mathrm{~W}_{t}\right) "+" \gamma_{Q, 1} 1.0 \mathrm{~T}_{h} "+" 0.6 \mathrm{~W} "$ \\
\hline WE & Wind and empty tank & $\gamma_{G, j}\left(\mathrm{~W}_{t}\right) "+0.6 W^{\prime \prime}$ \\
\hline SF & Earthquake on full tank & "( $\left(\mathrm{W}_{t}\right)^{\prime}+" E^{\prime \prime}+" 0.8 \mathrm{~T}_{h} "$ \\
\hline SE & Earthquake on empty tank & "(Wt $\left.\mathrm{W}_{\mathrm{t}}\right)^{\prime+} E^{\prime \prime}$ \\
\hline
\end{tabular}

In Table $5, W_{t}$ is tank self-weight, $E$ is earthquake load, $T$ is designed liquid height, $T_{h}$ is maximum liquid height, $S$ is snow load, and $W$ is wind load. 


\section{DESIGN BUCKLING STRESSES ACCORDING TO EUROCODE}

\subsection{Buckling strength evaluation}

When the tank wall is subjected to compressive stress, buckling of the steel course may occur. Buckling is characterized by a sudden sideways deflection of the steel plates of a cylinder. In cylinders (shells of revolution) there are 3 buckling stresses: meridional, circumferential, and shear [17]. The directions and each of the components are shown in Figure 2 [10].
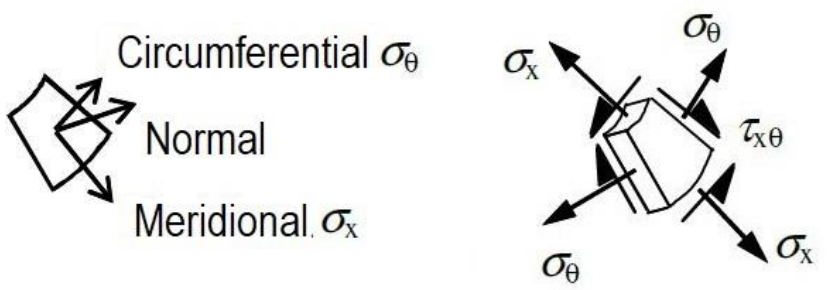

Figure 2 Directions and buckling stresses components [10]

According to [9], the safety of the shell structure of a circular silo should be evaluated by applying [10]. The analysis is performed according to EN 1993-1-6, Chapter 8. Annex D presents the expressions for buckling strength evaluation according to the stress design concept. Buckling strength is represented in terms of three stresses, meridional design buckling stress $\left(\sigma_{x, R d}\right)$, circumferential design buckling stress $\left(\sigma_{\theta, R d}\right)$, and in-plane shear design buckling stress $\left(T_{x \theta, R d}\right)$. These stresses are defined as characteristic yield stress $f_{y k}$ of steel reduced with factors related to buckling $\left(\mathrm{X}_{\mathrm{x}}, \mathrm{X}_{\theta}\right.$, and $\mathrm{X}_{\mathrm{T}}$ respectively):

$\sigma_{x, R d}=\chi_{x} \cdot f_{y k} / \gamma_{M 1}, \quad \sigma_{\theta, R d}=\chi_{\theta} \cdot f_{y k} / \gamma_{M 1}, \quad \tau_{x \theta, R d}=\chi_{\tau} \cdot f_{y k} / \gamma_{M 1} \cdot \sqrt{3}$

The factor of safety $\gamma_{\mathrm{M} 1}$ is taken as 1.1 according to [10]. The buckling reduction factors are defined as a function of the relative shell slenderness $\bar{\lambda}$ according to (16):

$\chi=\alpha / \bar{\lambda}^{2}$ for $\overline{\lambda_{p}} \leq \bar{\lambda}$

where $\alpha$ is elastic imperfection reduction factor, $\bar{\lambda}_{p}$ is plastic limit relative slenderness (17), in which $\beta$ is a plastic range factor of 0.6 according to [10], and $\bar{\lambda}$ is the relative slenderness of the shell expressed in three terms according to the evaluated stress component of design resistance (18).

$\overline{\lambda_{p}}=\sqrt{\alpha / 1-\beta}$

$\overline{\lambda_{x}}=\sqrt{f_{y k} / \sigma_{x, R c r}}, \overline{\lambda_{\theta}}=\sqrt{f_{y k} / \sigma_{\theta, R c r}}, \overline{\lambda_{\tau}}=\sqrt{f_{y k} / \sqrt{3} \cdot \tau_{x \theta, R c r}}$

In (16), $\sigma_{x, R c r}, \sigma_{\theta, R c r}$, and $\mathrm{T}_{x \theta, R c}$ are the elastic critical meridional, circumferential, and shear buckling stresses, respectively. The expressions given in [10], Annex $D$, define categories for cylinder shells (short, medium, long) according to the dimensionless length parameter $\omega$ :

$\omega=I / \sqrt{r \cdot t}$

where $/$ is the length of the cylinder, $t$ is the thickness of the shell, and $r$ is the radius at the middle surface of the cylinder. The method for determining the elastic critical buckling stresses for shells with a variable thickness are given in [8] (Annex D.2) and a detailed analysis is shown in [14]. The cylinder consists of 4 different sections and should be replaced by an equivalent cylinder comprising three sections. The fictitious wall thicknesses are $t_{a}=8.0 \mathrm{~mm}, t_{b}=8.5 \mathrm{~mm}$, and $t_{c}=11.0 \mathrm{~mm}$, while the lengths are $l_{a}=8.0 \mathrm{~m}$ and $l_{b}=I_{c}=4.0 \mathrm{~m}$. For $l_{a} / L=0.5, t_{b} / t_{a}=1.06$, and $t_{c} / t_{a}=1.38$, the factor $k$ is 0.6 . The total effective length of the equivalent single cylinder is $13.33 \mathrm{~m}$, with shell thickness of $t=t_{a}=8.0 \mathrm{~mm}$. The results obtained for the analyzed structure are presented in Tables 6 and 7 . 
Design of liquid-storage tank: results of software modeling vs calculations according to Eurocode

Table 6 Meridional buckling resistance

\begin{tabular}{|c|c|c|c|c|c|c|c|c|c|c|}
\hline course & $\mathrm{t}_{\mathrm{j}}[\mathrm{m}]$ & $\begin{array}{c}f_{y k} \\
{[\mathrm{MPa}]}\end{array}$ & $\begin{array}{l}\sigma_{\mathrm{x}, \mathrm{Rcr}} \\
{[\mathrm{MPa}]}\end{array}$ & $\bar{\lambda}_{x}$ & $\alpha_{x}$ & $\bar{\lambda}_{p}$ & $\chi_{x}$ & $\begin{array}{r}\sigma_{x, R k} \\
{[\mathrm{MPa}]}\end{array}$ & $\begin{array}{c}\sigma_{x, R d} \\
{[\mathrm{MPa}]}\end{array}$ & $\begin{array}{r}\sigma_{x, R d, E} \\
{[\mathrm{MPa}]}\end{array}$ \\
\hline 1 & 0.012 & \multirow{4}{*}{235} & 147.38 & 1.26 & 0.28 & 0.84 & 0.18 & 42.30 & 38.45 & 42.30 \\
\hline 2 & 0.010 & & 122.81 & 1.38 & 0.26 & 0.81 & 0.14 & 32.90 & 29.91 & 32.90 \\
\hline 3 & 0.009 & & 110.53 & 1.46 & 0.25 & 0.80 & 0.12 & 28.20 & 25.64 & 28.20 \\
\hline $4-8$ & 0.008 & & 98.24 & 1.55 & 0.23 & 0.76 & 0.10 & 23.50 & 21.36 & 23.50 \\
\hline
\end{tabular}

Table 7 Circumferential buckling resistance

\begin{tabular}{|c|c|c|c|c|c|c|c|c|c|}
\hline course & $\mathrm{t}_{\mathrm{j}}[\mathrm{m}]$ & $\begin{array}{c}f_{y k} \\
{[\mathrm{MPa}]}\end{array}$ & $\begin{array}{c}\sigma_{\theta, R c r} \\
{[\mathrm{MPa}]}\end{array}$ & $\bar{\lambda}_{\theta}$ & $\alpha_{\theta}$ & $\bar{\lambda}_{p}$ & $\chi_{\theta}$ & $\begin{array}{l}\sigma_{\theta, R k} \\
{[\mathrm{MPa}]}\end{array}$ & $\begin{array}{l}\sigma_{\theta, R d} \\
{[\mathrm{MPa}]}\end{array}$ \\
\hline 1 & 0.012 & \multirow{4}{*}{235} & 2.15 & 10.45 & \multirow{4}{*}{0.75} & \multirow{4}{*}{1.37} & 0.0069 & 1.32 & 1.19 \\
\hline 2 & 0.010 & & 2.58 & 9.54 & & & 0.0082 & 1.93 & 1.75 \\
\hline 3 & 0.009 & & 2.78 & 9.19 & & & 0.0088 & 2.07 & 1.88 \\
\hline $4-8$ & 0.008 & & 3.22 & 8.54 & & & 0.0102 & 2.40 & 2.18 \\
\hline
\end{tabular}

\subsection{Maximum compression force at the bottom of the shell}

The maximum compression force at the bottom of the tank wall $W_{b}=390.14 \mathrm{kN} / \mathrm{m}^{\prime}$, expressed in $\mathrm{kN}$ per meter of wall circumference, is determined according to [13].

$W_{b}=W_{t}+\left(1.273 \cdot M / D^{2}\right)$

where $\mathrm{W}_{\mathrm{t}}=11.65 \mathrm{kN} / \mathrm{m}$ is self-weight of the tank shell and roof, and $\mathrm{M}$ is the overturning moment calculated earlier.

\subsection{Design effect buckling stresses}

According to EN 1993-1-6 Annex A.2, the membrane stress components for each of the loads are calculated in one (center) point for every course. The calculated values of the design-effect buckling stresses are listed in Tables 8 to 12. The meridional buckling stress is determined using expression:

$$
\sigma_{x}=-F_{x} / 2 \pi r t
$$

where $F_{x}$ is the acting force in the vertical direction. The circumferential buckling stress is obtained from

$\sigma_{\theta}=p_{n} \cdot r / t$

where $p_{n}$ is pressure value perpendicular to the shell curve.

Table 8 Meridional buckling stress from self-weight (W) and snow (S)

\begin{tabular}{|c|c|c|c|c|c|c|c|}
\hline cou. & $z[m]$ & $t[\mathrm{~mm}]$ & $r[\mathrm{~mm}]$ & $F_{x, W}[N]$ & $F_{x, S}[N]$ & $\sigma_{x, E d, W}[\mathrm{MPa}]$ & $\sigma_{x, E d, S}[\mathrm{MPa}]$ \\
\hline 1 & 0 & 12 & 10344 & 772262 & \multirow{8}{*}{154720} & 0.99 & 0.20 \\
\hline 2 & 2 & 10 & 10345 & 649753 & & 1.00 & 0.24 \\
\hline 3 & 4 & 9 & 10345.5 & 547664 & & 0.94 & 0.26 \\
\hline 4 & 6 & \multirow{5}{*}{8} & \multirow{5}{*}{10346} & 455784 & & 0.88 & 0.30 \\
\hline 5 & 8 & & & 374113 & & 0.72 & 0.30 \\
\hline 6 & 10 & & & 292442 & & 0.56 & 0.30 \\
\hline 7 & 12 & & & 210771 & & 0.41 & 0.30 \\
\hline 8 & 14 & & & 129100 & & 0.25 & 0.30 \\
\hline
\end{tabular}

The most critical case of snow load, Case I (uniformly distributed snow across the entire roof surface), gives the highest meridional stress, $s_{1}=0.40 \mathrm{kN} / \mathrm{m}^{2}$. The roof dome area is $A_{r}=\pi\left(r^{2}+h^{2}\right)=\pi\left(10.35^{2}+4.0^{2}\right)=386.8 \mathrm{~m}^{2}$, the 
total snow load is $F_{x}=s_{1} \cdot A_{r}=0.40 \cdot 386.8=154.72 \mathrm{kN}$, and the snow load per meter of cylinder circumference is $\mathrm{F}_{\mathrm{x}} / \mathrm{O}=154.72 / 65=2.38 \mathrm{kN} / \mathrm{m}^{\prime}$.

According to [10], Annex D, expression (23) is used to determine the circumferential buckling stress.

The values $q_{e q}$ are in Table 2 and $q_{s}$ is $-0.48 \mathrm{kN} / \mathrm{m}^{2}$.

$$
\sigma_{\theta, E d}=\left(q_{e q}+q_{s}\right)(r / t)
$$

Table 9 Circumferential buckling stress from wind and suction load

\begin{tabular}{|c|c|c|c|c|c|c|c|c|c|}
\hline cou. & $\mathrm{t}[\mathrm{mm}]$ & $\mathrm{r}[\mathrm{mm}]$ & $\omega$ & $C_{\theta}$ & $\mathrm{k}_{\mathrm{w}}$ & $\mathrm{q}_{\mathrm{w}, \max }\left[\mathrm{kN} / \mathrm{m}^{2}\right]$ & $\mathrm{q}_{\mathrm{eq}}\left[\mathrm{kN} / \mathrm{m}^{2}\right]$ & $\mathrm{q}_{\mathrm{s}}\left[\mathrm{kN} / \mathrm{m}^{2}\right]$ & $\sigma_{\theta, E d}[\mathrm{MPa}]$ \\
\hline 1 & 12 & 10344 & 5.68 & \multirow{8}{*}{1.0} & 1.03 & 0.39 & 0.39 & \multirow{8}{*}{0.48} & 0.75 \\
\hline 2 & 10 & 10345 & 6.22 & & 1.05 & 0.82 & 0.82 & & 1.34 \\
\hline 3 & 9 & 10345.5 & 6.55 & & 1.07 & 0.92 & 0.92 & & 1.61 \\
\hline 4 & \multirow{5}{*}{8} & \multirow{5}{*}{10346} & 6.95 & & 1.09 & 1.00 & 1.00 & & 1.91 \\
\hline 5 & & & 6.95 & & 1.09 & 1.05 & 1.05 & & 1.98 \\
\hline 6 & & & 6.95 & & 1.09 & 1.11 & 1.11 & & 2.06 \\
\hline 7 & & & 6.95 & & 1.09 & 1.15 & 1.15 & & 2.11 \\
\hline 8 & & & 6.95 & & 1.09 & 1.19 & 1.19 & & 2.16 \\
\hline
\end{tabular}

Table 10 presents the circumferential buckling stresses for two design situations: load from liquid in operational level of $15 \mathrm{~m}(\mathrm{~T})$, and load from liquid when tank is full (16 m height, $\mathrm{T}_{\mathrm{h}}$ ).

Table 10 Circumferential buckling stress from stored liquid

\begin{tabular}{|c|c|c|c|c|c|}
\hline cou. & $t[\mathrm{~mm}]$ & $r[\mathrm{~mm}]$ & $T_{h}, T\left[k N / m^{2}\right.$ & $\sigma_{\theta, E d, T_{h}}[\mathrm{MPa}]$ & $\sigma_{\theta, E d, T}[\mathrm{MPa}]$ \\
\hline 1 & 12 & 10344 & 150,140 & 129.30 & 120,68 \\
\hline 2 & 10 & 10345 & 130,120 & 134.49 & 124.14 \\
\hline 3 & 9 & 10345.5 & 110,100 & 126.45 & 114.95 \\
\hline 4 & \multirow{5}{*}{8} & \multirow{5}{*}{10346} & 90,80 & 116.39 & 103.46 \\
\hline 5 & & & 70,60 & 90.53 & 77.60 \\
\hline 6 & & & 50,40 & 64.66 & 51.73 \\
\hline 7 & & & 30,20 & 38.80 & 25.87 \\
\hline 8 & & & 10,0 & 12.93 & 0.00 \\
\hline
\end{tabular}

The meridional buckling stress caused by an earthquake load is determined from the maximum compression force at the bottom of the shell $W_{b}$, and thickness of the shell $t_{b s}$, without corrosion reserve of $1 \mathrm{~mm}$, as follows: $\sigma_{\mathrm{x}, \mathrm{Ed}}=\mathrm{W} / \mathrm{t}_{\mathrm{bs}}=390.14 / 0.011=35.5 \mathrm{MPa}$.

The circumferential buckling stress caused by the earthquake is calculated from a combined hydrodynamic pressure using expression (22). The values are listed in Table 11.

Table 11 Circumferential buckling stress due to earthquake

\begin{tabular}{|c|c|c|c|c|c|}
\hline cou & $\mathrm{z}[\mathrm{m}]$ & $t[\mathrm{~mm}]$ & $r[\mathrm{~mm}]$ & $p_{v}[\mathrm{MPa}]$ & $\sigma_{\theta, E d}[\mathrm{MPa}]$ \\
\hline 1 & 0.1 & 12 & 10344 & 0.086 & 74.13 \\
\hline 2 & 2 & 10 & 10345 & 0.080 & 82.76 \\
\hline 3 & 4 & 9 & 10345.5 & 0.071 & 81.61 \\
\hline 4 & 6 & \multirow{5}{*}{8} & \multirow{5}{*}{10346} & 0.061 & 78.89 \\
\hline 5 & 8 & & & 0.050 & 64.66 \\
\hline 6 & 10 & & & 0.036 & 46.56 \\
\hline 7 & 12 & & & 0.022 & 28.45 \\
\hline 8 & 14 & & & 0.008 & 10.35 \\
\hline
\end{tabular}

Starting from the design stresses listed in Tables 8 to 11, the load combinations for the given example have been calculated according to the combinations presented in Table 5. The total stress values are in Table 12. 
Design of liquid-storage tank: results of software modeling vs calculations according to Eurocode

Table 12 Design effect buckling stresses - total results for combinations

\begin{tabular}{|c|c|c|c|c|c|c|c|c|c|c|}
\hline \multirow{3}{*}{ §̊ } & \multicolumn{10}{|c|}{ Combinations, Ed, [MPa] } \\
\hline & \multicolumn{2}{|c|}{$\mathrm{Dil}$} & \multicolumn{2}{|c|}{$S$} & \multicolumn{2}{|c|}{ WE } & \multicolumn{2}{|c|}{ WF } & \multicolumn{2}{|c|}{ SF } \\
\hline & $\sigma_{x, E d}$ & $\sigma_{\theta, E d}$ & $\sigma_{x, E d}$ & $\sigma_{\theta, E d}$ & $\sigma_{x, E d}$ & $\sigma_{\theta, E d}$ & $\sigma_{x, E d}$ & $\sigma_{\theta, E d}$ & $\sigma_{x, E d}$ & $\sigma_{\theta, E d}$ \\
\hline 1 & -1.52 & 181.02 & -1.52 & 181.02 & -1.34 & -0.67 & -1.34 & 192.83 & -35.50 & 177.57 \\
\hline 2 & -1.52 & 186.21 & -1.52 & 186.21 & -1.31 & -1.21 & -1.31 & 199.71 & & 190.35 \\
\hline 3 & -1.46 & 172.43 & -1.46 & 172.43 & -1.22 & -1.45 & -1.22 & 187.25 & & 182.77 \\
\hline 4 & -1.35 & 155.19 & -1.35 & 155.19 & -1.08 & -1.72 & -1.08 & 171.73 & & 172.00 \\
\hline 5 & -1.13 & 116.39 & -1.13 & 116.39 & -0.87 & -1.78 & -0.87 & 132.82 & & 137.08 \\
\hline 6 & -0.92 & 77.60 & -0.92 & 77.60 & -0.65 & -1.85 & -0.65 & 93.91 & & 98.29 \\
\hline 7 & -0.71 & 38.80 & -0.71 & 38.80 & -0.44 & -1.90 & -0.44 & 55.03 & & 59.49 \\
\hline 8 & -0.44 & 0.00 & -0.44 & 0.00 & -0.17 & -1.94 & -0.17 & 16.16 & & 20.69 \\
\hline
\end{tabular}

\section{NUMERICAL ANALYSIS USING SOFTWARE}

\subsection{Model}

The numerical modeling and analysis is done using a commercial building-structural analysis and design software, Scia Engineer 17.01 [18]. Each course is modeled as a shell with the corresponding design thicknesses. The shell of the tank is modeled with the Scia shell (98) 2D finite element of constant thickness, isotropic properties, and with a centrally positioned mid-plane. At the top of the cylinder there is a circular upright ring modeled with $1 \mathrm{~d}$ beam (80) type elements rigidly bound to the shell elements. The dimensions of the finite element are $0.5 \times 0.5 \mathrm{~m}$.

\subsection{Loads and combinations}

Loads are applied on the shell elements using the program ability to generate loads perpendicular to the elements from the free load projection. The impact of water during the earthquake is modeled as mass distributed equally on the shell elements. The total water mass is $77492.7 \mathrm{~kg} / \mathrm{m}$, and thus, the distributed mass is $322.88 \mathrm{~kg} / \mathrm{m}^{2}$.

\subsection{Results of modal and response spectrum (linear dynamic) analysis}

The modal analysis polynomial method was used to calculate a total of 3000 modes, and $92 \%$ of the total mass was activated. Figures 3,4 , and 5 are showing the three main modes that activated most of the cylinder mass.

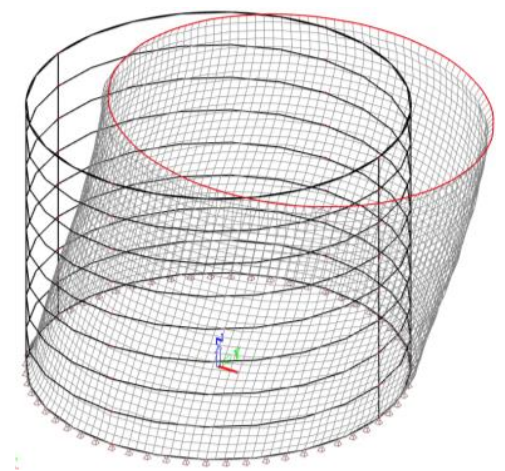

Figure 3 Mode 405. $\mathrm{T}=0.076 \mathrm{~s}$; $F=13.1 \mathrm{~Hz}$; translation $\mathrm{X} ; 58 \%$

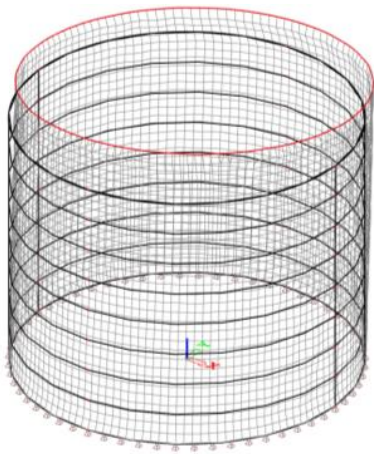

Figure 4 Mode 406. $\mathrm{T}=0.076 \mathrm{~s}$; $\mathrm{F}=13.1 \mathrm{~Hz}$; translation $\mathrm{Y} ; \mathbf{5 8 \%}$

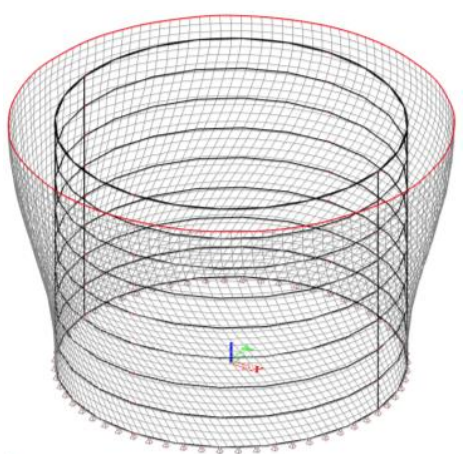

Figure 5 Mode 884. T=0.046 s; $\mathrm{F}=21.43 \mathrm{~Hz}$; rotation $\mathrm{Z} ; 78 \%$

The Kirchhoff method is used in the solver setup. The software results are represented with main stresses: sigy+ is the main stress on the outer face of the shell, and sigy- is the stress on the inside face. The meridional stress is calculated with expression (24). The same procedure was used for the circumferential stress in expression (25).

Gulin, M, Uzelac, I, Dolejš, J, Boko, I 


$$
\begin{aligned}
& \sigma_{x, E d}^{F E M}=\left[\left(\text { sigy }^{+}\right)+(\text {sigy- })\right] / 2[\mathrm{MPa}] \\
& \sigma_{\theta, E d}^{F E M}=\left[\left(\text { sigx }^{+}\right)+(\text {sigx }-)\right] / 2[\mathrm{MPa}]
\end{aligned}
$$

The elastic response spectrum type 1 was used in the linear dynamic analysis, for behavior factor $q=1.0$, design ground acceleration $\mathrm{a}_{\mathrm{g}}=0.22 \mathrm{~g}$, and ground type $\mathrm{A}$ (rock). The results for the seismic combination SF, meridional buckling stress are shown on Figures 6 and 7 (focusing on first coarse). Figures 8 and 9 show the circumferential stresses for the entire cylinder.
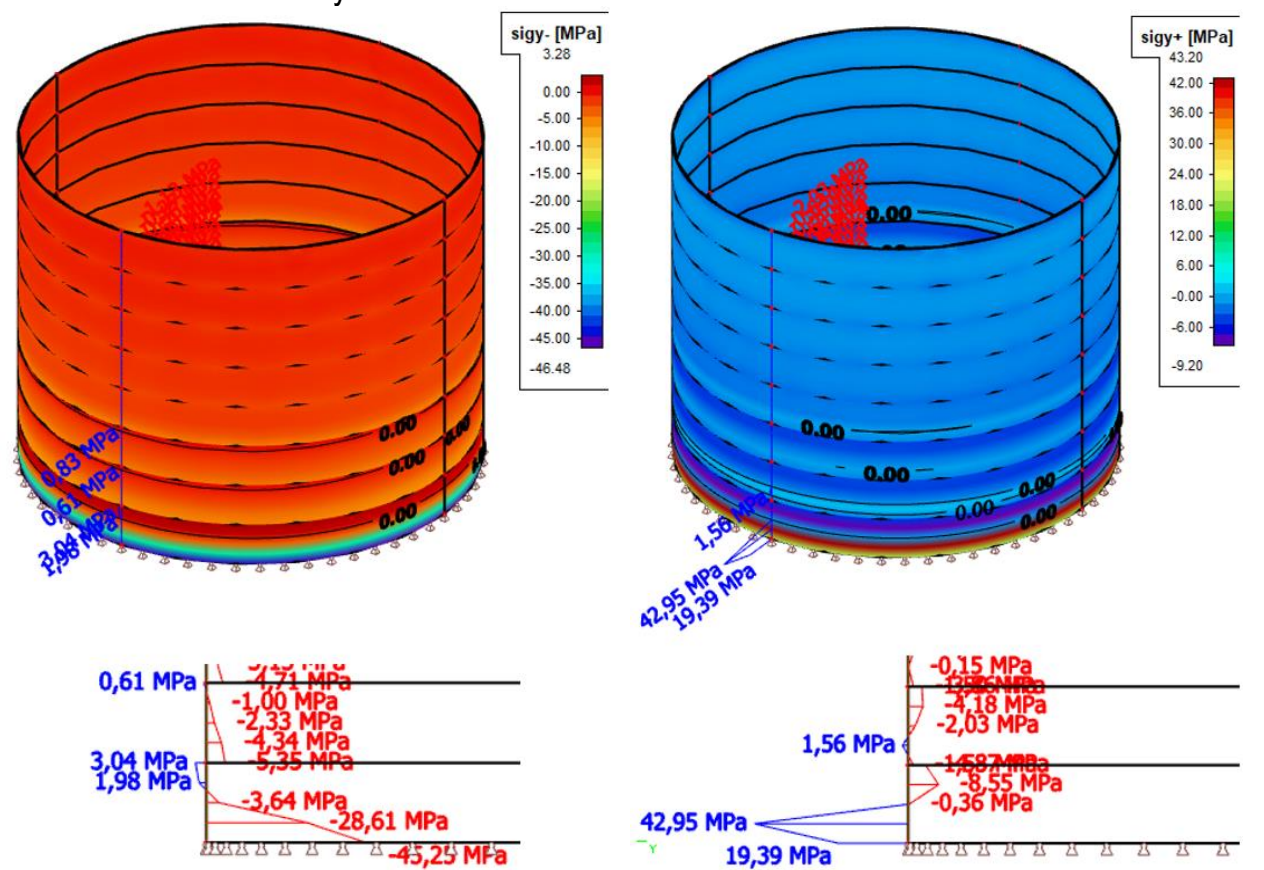

Figure 6 Meridional stress for combination SF, inside face of shell

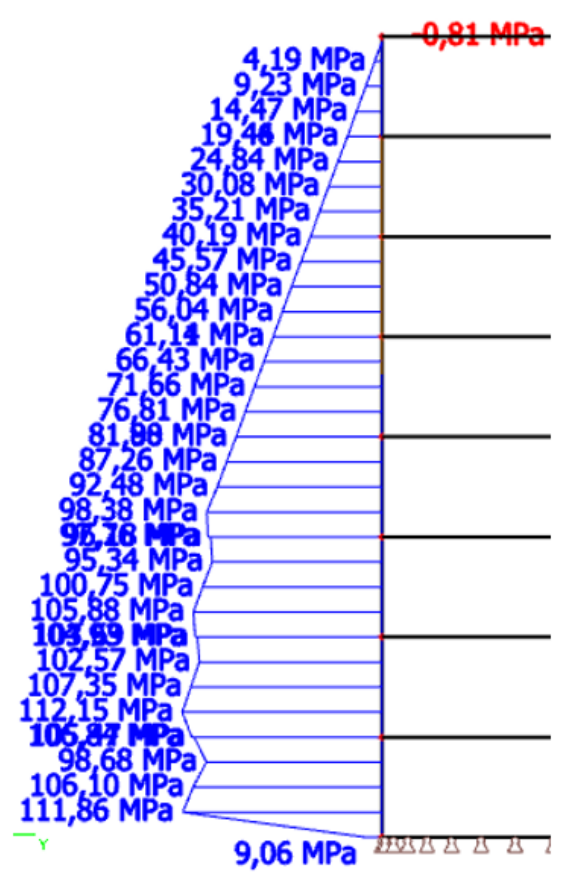

Figure 7 Meridional stress for combination SF, outside face of shell

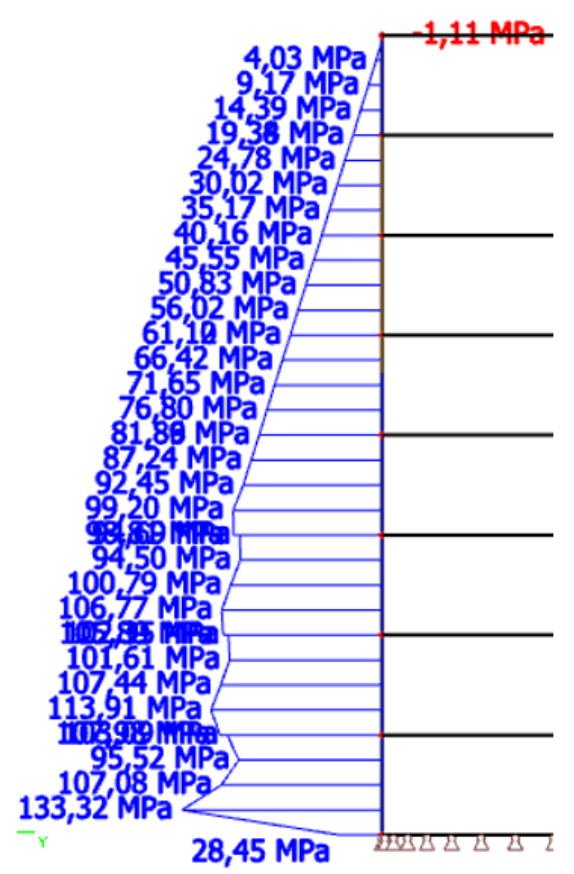

Figure 8 Circumferential stress for combination SF, inside face of shell

Figure 9 Circumferential stress for combination $\mathrm{SF}$, outside face of shell

Gulin, M, Uzelac, I, Dolejšs, J, Boko, I 


\subsection{Results of linear static analysis}

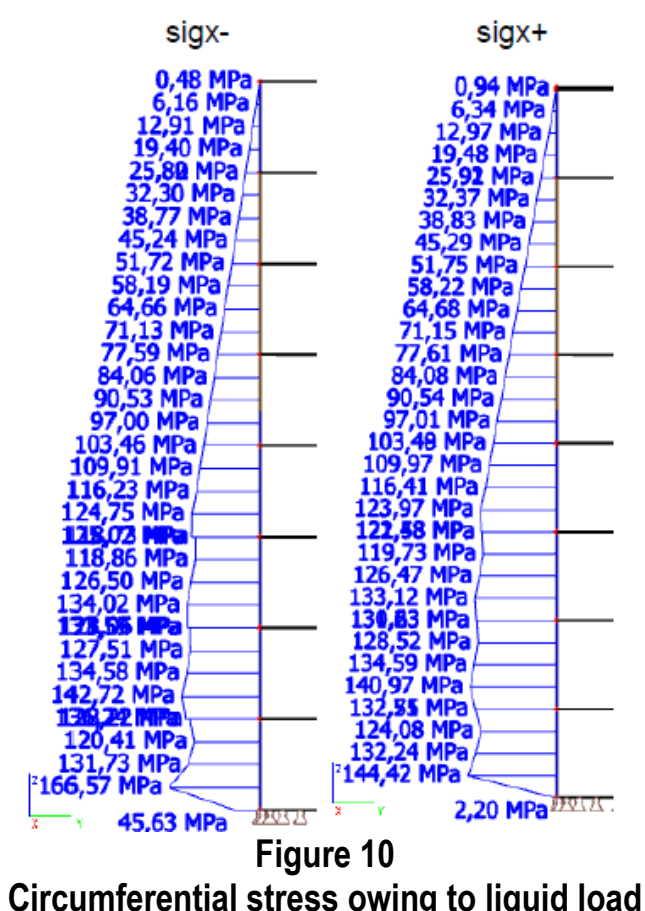

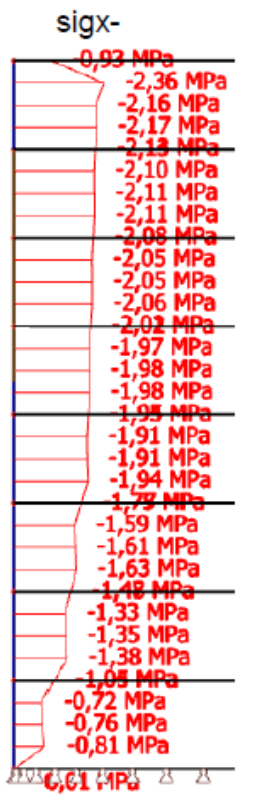

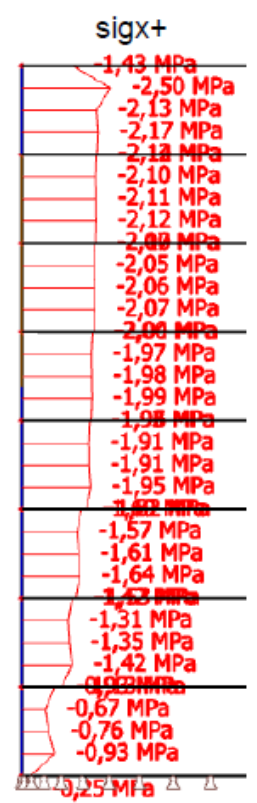

Figure 11

Some results of the linear static analysis are shown in Figures 10 and 11. The combinations are generated manually (principle of superposition) and the global results for the FEM analysis are presented in Table 13.

Table 13 Results of FEM analysis - combination results

\begin{tabular}{ccccccccccc}
\hline \multirow{2}{*}{ cou. } & \multicolumn{2}{c}{ D and I } & \multicolumn{2}{c}{ S } & \multicolumn{2}{c}{ WE } & \multicolumn{2}{c}{ WF } & \multicolumn{2}{c}{ SF } \\
\cline { 2 - 10 } & merid. & circum. & merid & circum. & merid & circum. & merid & circum. & merid & circum. \\
\hline 1 & -1.36 & 110.20 & -1.36 & 184.80 & -1.18 & -0.68 & -1.18 & 199.75 & -12.93 & 106.59 \\
\hline 2 & -1.42 & 110.59 & -1.42 & 186.35 & -1.21 & -1.22 & -1.21 & 200.81 & 107.4 \\
\hline 3 & -1.35 & 102.04 & -1.35 & 172.48 & -1.12 & -1.45 & -1.12 & 188.32 & 100.77 \\
\hline 4 & -1.31 & 91.56 & -1.31 & 155.46 & -1.04 & -1.72 & -1.04 & 172.83 & 92.47 \\
\hline 5 & -1.11 & 68.06 & -1.11 & 116.40 & -0.84 & -1.78 & -0.84 & 134.02 & 71.66 \\
\hline 6 & -0.88 & 44.71 & -0.88 & 77.60 & -0.61 & -1.85 & -0.61 & 95.16 & 50.84 \\
\hline 7 & -0.69 & 21.38 & -0.69 & 38.81 & -0.42 & -1.90 & -0.42 & 55.93 & 30.08 \\
\hline 8 & -0.47 & -1.05 & -0.47 & 1.47 & -0.21 & -1.93 & $-0,21$ & 17.51 & 9.23 \\
\hline
\end{tabular}

\section{COMPARISON OF RESULTS}

In Table 14, the results of the FEM analysis obtained with Scia Engineer are compared with those obtained by Eurocode guidelines. Negative percentages means that values obtained from the software are smaller than those from the Eurocode analysis. From Table 14, it can be seen that the meridian stress results obtained by the FEM analysis in most cases are 3 to $12 \%$ lower than the results according to the Eurocode. The values of circumferential stresses are to some extent similar in both approaches, with the difference in most cases not exceeding $3 \%$. The analysis of the earthquake combination gives the meridian stress value only at the critical point directly above the ground, and thus, it is compared to the point above the base in the numerical model. There is a noticeable difference 
Design of liquid-storage tank: results of software modeling vs calculations according to Eurocode

of about $63 \%$ in the results of the meridional stress at the critical point. In Figures 6 and 7 , the main stresses values are showing that the bending effect is also significant.

Table 14 Results comparison

\begin{tabular}{|c|c|c|c|c|c|c|c|c|c|c|}
\hline \multirow{2}{*}{ cou. } & \multicolumn{2}{|c|}{$\mathrm{D}$ and $\mathrm{I}$} & \multicolumn{2}{|c|}{$S$} & \multicolumn{2}{|c|}{ WE } & \multicolumn{2}{|c|}{ WF } & \multicolumn{2}{|c|}{ SF } \\
\hline & merid & circum & merid & circum & merid & circum & merid & circum & merid & circum \\
\hline 1 & $-11 \%$ & $2 \%$ & $-11 \%$ & $2 \%$ & $-12 \%$ & $1 \%$ & $-12 \%$ & $3 \%$ & $-63.6 \%$ & $-30.5 \%$ \\
\hline 2 & $-6 \%$ & $0 \%$ & $-6 \%$ & $0 \%$ & $-8 \%$ & $0 \%$ & $-8 \%$ & $0 \%$ & & $-22.9 \%$ \\
\hline 3 & $-7 \%$ & $0 \%$ & $-7 \%$ & $0 \%$ & $-8 \%$ & $0 \%$ & $-8 \%$ & $0 \%$ & & $-19.0 \%$ \\
\hline 4 & $-3 \%$ & $0 \%$ & $-3 \%$ & $0 \%$ & $-4 \%$ & $0 \%$ & $-4 \%$ & $0 \%$ & & $-14.7 \%$ \\
\hline 5 & $-2 \%$ & $0 \%$ & $-2 \%$ & $0 \%$ & $-3 \%$ & $0 \%$ & $-3 \%$ & $0 \%$ & & $-9.8 \%$ \\
\hline 6 & $-4 \%$ & $0 \%$ & $-4 \%$ & $0 \%$ & $-6 \%$ & $0 \%$ & $-6 \%$ & $0 \%$ & & $-8.4 \%$ \\
\hline 7 & $-3 \%$ & $0 \%$ & $-3 \%$ & $0 \%$ & $-5 \%$ & $0 \%$ & $-5 \%$ & $-1 \%$ & & $-5.4 \%$ \\
\hline 8 & $9 \%$ & $-46 \%$ & $9 \%$ & - & $25 \%$ & $-1 \%$ & $25 \%$ & $0 \%$ & & $-10.8 \%$ \\
\hline
\end{tabular}

\section{CONCLUSIONS}

The stress values in the tank wall used as example are obtained using the European standards and FEM numerical model, i.e., commercial building structural analysis and design software Scia Engineer [18]. The analysis for circumferential and meridional buckling stress was performed for all load combinations defined by standards [7] and [8]. A procedure for determining the stresses and resistances according to the norms has been shown, and these values (stresses) are later compared with the numerical FEM results. The differences between the stress values calculated according to the Eurocode guidelines and those obtained by the numerical 2D FEM model are shown. The reason for significant deviations in the seismic combination is probably due to the simplified representation of liquid used in the numerical model, which cannot take into account all the assumptions in the seismic method introduced by the Eurocode. Water is modeled as a mass uniformly distributed on the tank wall, and thus, it is not possible to simulate fluid viscosity and interaction fluid-tank wall.

This paper has shown that simplified numerical models with 2D finite elements can provide satisfactory results for static analysis, but because of the complexity and the specificity of the problem of water-tank wall interaction during an earthquake, such models do not yield reliable results. When modeling those problems, it is recommended to use software tools that can analyze 3D structural solid elements, which can be used to precisely define fluid properties and fluid-solid interactions.

\section{References}

[1] Tank - Definition of Tank by "Merriam-Webster" web dictionary, https://www.merriamwebster.com/dictionary/tank, Accessed 14 November 2017

[2] Zdravkov, L: ASTanks.com - publication, http://www.astanks.com/Tanks/T EN/Intro EN.html, Accessed 14 November 2017

[3] Anand, J.: Stress analysis of storage tank piping - web presentation, https://www.slideshare.net/JebaAnandNadar/stress-analysis-of-storage-tank-piping-jeba-anand, Accessed 14 November 2017

[4] Jerath, S.; Lee, M. 2015: Stability analysis of cylindrical tanks under static and earthquake loading, Journal of Civil Engineering and Architecture, 9, pp. 72-79, https://doi.org/10.17265/1934-7359/2015.01.009

[5] Godoy, L.; Mendez-Degró, J. : Introduction to above ground steel tanks, Facultad de Ciencias Exactas, Físicas y NaturalesSede Ciudad Universitaria, Argentina, http://www.efn.unc.edu.ar/investigacion/elearning/tanques/documentos/pub/typestanks.pdf, Accessed 18 November 2017 
[6] Skejić, D.; Cavor, M. 2015: Parametric analysis of the buckling resistance of the silo steel wall, Electronic Journal of the Faculty of Civil Engineering Osijek-e-GFOS, 10, pp. 47-57, https://doi.org/10.13167/2015.10.6

[7] EN 1990, 2002: Eurocode - Basis of structural design, European Committee for Standardization, Brussels

[8] EN 1991-4, 2004: Eurocode 1 - Actions on structures - Part 4: Silos and Tanks, European Committee for Standardization, Brussels

[9] EN 1993-4-2, 2004: Eurocode 3 - Design of steel structure - Part 4 - 2: Tanks, European Committee for Standardization, Brussels

[10] EN 1993-1-6, 2004: Eurocode 3 - Design of steel structures - Part 1 - 6: Strength and Stability of Shell Structures, European Committee for Standardization, Brussels

[11] EN 1998-1, 2004: Eurocode 8 - Design of structures for earthquake resistance - Part 1: General rules, seismic actions and rules for buildings, European Committee for Standardization, Brussels

[12] EN 1998-4, 2006: Eurocode 8 - Design of structures for earthquake resistance - Part 4: Silos, tank and pipelines, European Committee for Standardization, Brussels

[13] EN 14015, 2004: Specification for the design and manufacture of site built, vertical, cylindrical, flat-bottomed, above ground, welded, steel tanks for the storage of liquids at ambient temperature and above, European Committee for Standardization, Brussels

[14] Gulin, M. 2017: Design of liquid-storage tanks: results of software modeling vs calculations according to Eurocode, Faculty of civil engineering architecture and geodesy, University of Split, Master thesis, https://urn.nsk.hr/urn:nbn:hr:123:703589

[15] EN 1991-1-3, 2012: Eurocode 1 - Actions on structures - Part 1 - 3: General actions - Snow loads, European Committee for Standardization, Brussels

[16] EN 1991-1-4, 2005: Eurocode 1 - Actions on structures - Part 1 - 4: General actions - Wind actions, European Committee for Standardization, Brussels

[17] Thorup, M.; Knudsen, K. 2016: Buckling of Steel Shell Structures, School of Engineering and Science Department of Civil Engineering, Aalborg University

[18] Official web page of the software "Scia Engineer", https://www.scia.net/en/support/downloads Accessed 3 May 2017

How to cite this article:

Gulin, M.; Uzelac, I.; Dolejš, J.; Boko, I.: Design of liquid-storage tank: results of software modeling vs calculations according to Eurocode, Electronic Journal of the Faculty of Civil Engineering Osijek-e-GFOS, 15, pp. 85-97, https://doi.org/10.13167/2017.15.8 